\title{
IMPACT OF WHEY PROTEIN SUPPLEMENTATIONS ON FERTILITY PARAMETERS OF ADULT MALE GYM-GOERS
}

\author{
By
}

\section{Ali Ramadan Rabie, Ahmad Kamel Seddeik Abdel-Hameed and Abul Fetouh Khaled Abul Fetouh Mohammed*}

Departments of Dermatology, Venereology and Andrology, Al-Azhar Faculty of Medicine and Zagazig Faculty of Medicine*

\begin{abstract}
Background: Whey proteins are widely used by adult male gym-goers as a muscle-building supplement to improve their physical appearance.

Objectives: The current study aimed to investigate the impact of this practice on fertility capacity.

Subjects and Methods: Forty adult male gym-goers, recruited during the period between August 2016 and April 2017, received whey protein supplementation (Gold Standard 100\% Whey ${ }^{\mathrm{TM}}$, 15 gram daily) during their gym training for 12 weeks. Body mass index (BMI), lean body mass, semen analysis and hormonal profile (FSH, LH, PRL, T and oestrogen) were evaluated at the beginning and the end of the study.

Results: A total of 33 participants completed the study. There were significant increases in mean BMI, mean lean body mass, and mean progressively motile sperms. Changes in semen volume, sperm count and hormonal levels were all non-significant.

Conclusion: Whey protein supplementations did not have any negative impact on fertility capacity. Further larger and randomized controlled trials are needed to confirm these results.
\end{abstract}

Key words: Nutritional supplementation, exercise, fertility.

\section{INTRODUCTION}

Whey protein represents $20 \%$ of milk proteins. It is derived from the watery portion of milk which separates from the curds during the process of cheese production (Tsutsumi and Tsutsumi, 2014).

Whey proteins contain high concentrations of branched-chain amino acids (BCAAs) (Millward et al., 2008), which are easily digested and rapidly increase the postprandial plasma BCAA levels (Salehi et al., 2012). BCAAs stimulate muscle protein synthesis, prevent muscle protein breakdown, and may ameliorate exercise-induced muscle damage and pain (Volek et al., 2013). These properties of whey proteins explain their common use in the exercise industry as a muscle-building supplement (Josse and Phillips, 2012).

Whey protein supplementations have become a common practice among gymgoers due to their expected benefit regarding performance enhancement and muscle building (Samal and Samal, 2017).

Although whey protein supplementations are generally considered 
safe for most adults when used appropriately (Tsutsumi and Tsutsumi, 2014), the possible impact of these supplementations on the fertility potential of adult males is not known.

The aim of the current study was to examine the possible effects of whey protein supplementations on the fertility parameters of adult male gym-goers.

\section{SUBJECTS AND METHODS}

Participants: Forty adult males aged between 18 and 33 years (mean $\pm \mathrm{SD}=$ $24.95 \pm 3.88$ year) were enrolled into the current study. Participants were recruited consecutively during the period between August 2016 and April 2017. All participants engaged in a gym training program while receiving whey protein supplementation for 12 weeks.

Gym training program: Participants engaged in a supervised gym training program consisting of $60-90$ minutes daily, 3 days per week for 12 weeks (day 1: shoulders/chest/triceps, day 2: back/biceps, day 3: legs).

Supplementation regimen: Participants received whey protein supplementation (Gold Standard 100\% Whey $^{\mathrm{TM}}$ ) 15 grams daily for 12 weeks. During the training days, participants ingested the supplement prior to the workout.

Clinical and laboratory measurements: All participants underwent thorough history taking, complete physical and genital examination, body mass index (BMI) and lean body mass calculation. BMI was calculated using the formula: BMI = weight $(\mathrm{Kg}) /$ height2 $(\mathrm{Kg} / \mathrm{m} 2)$. Lean body mass was calculated using the Hume formula for men: LBM $(\mathrm{Kg})=$ $0.32810 \mathrm{x}$ weight $(\mathrm{Kg})+0.33929 \mathrm{x}$ height $(\mathrm{Cm})$ - 29.5336. Semen analysis of all participants was performed according to the WHO 2010 laboratory manual (World Health Organization, 2010). Reproductive hormonal profile assessment included serum levels of FSH, LH, prolactin (PRL), total testosterone (T) and total oestrogen. All these measurements were performed at the beginning of the study and 12 weeks later.

\section{Ethical considerations:}

The study protocol was approved by the research ethics committee of the Faculty of Medicine, Al-Azhar University. The nature of the study was explained to all participants who gave an informed consent.

\section{Statistical Analysis:}

Statistical analysis was performed using the IBM SPSS Statistics software (SPSS version 23.0). The continuous data are presented as range (mean $\pm \mathrm{SD}$ ). The paired student's t-test was used to compare these data at the baseline and at the end of the study. $\mathrm{P}$ value $\leq 0.05$ was considered significant.

\section{RESULTS}

Forty adult male gym attendants were initially recruited at the beginning of the study. Participants aged between 18 and 33 years (mean $\pm \mathrm{SD}=24.95 \pm 3.88$ year).
At the end of the 12-week duration of the study, 7 (17.5\%) participants were lost to follow-up and excluded from the study. Therefore, a total of 33 participants completed the study. 
Compared to the initial baseline, there was a significant increase in mean BMI (from 24.69 to $25.01 \mathrm{Kg} / \mathrm{m} 2, \mathrm{P}=0.04$ ) and mean lean body mass (from 59.39 to $59.78 \mathrm{Kg}, \mathrm{P}=0.05$ ) at the end of the study.

Semen volume and sperm count showed non-significant increases $(\mathrm{P}=$ $0.42, \mathrm{P}=0.5$ respectively). There was, however, a significant increase in the percentage of the progressively motile $(\mathrm{A}+\mathrm{B})$ sperms at the end of the 12-week period (from $62.73 \%$ to $65.76 \%, \mathrm{P}=0.05$ ) (Table 1).

All changes in the hormonal profile levels (FSH, LH, prolactin, total testosterone and total oestrogen) were non-significant (Table 1).

Table (1): Changes in the studied population characteristics at the end of the study (n $=33$, $P$ value using the paired student's t-test).

\begin{tabular}{|c|c|c|c|}
\hline $\begin{array}{l}\text { Duration } \\
\text { Parameters }\end{array}$ & Base line & After 12 weeks & $\mathbf{P}$ \\
\hline BMI $\left(\mathrm{Kg} / \mathrm{m}^{2}\right)$ & $\begin{array}{c}22.86-26.87(24.69 \pm \\
0.82)\end{array}$ & $\begin{array}{c}22.53-26.26(25.01 \pm \\
0.68)\end{array}$ & 0.04 \\
\hline Lean body mass (Kg) & $51.6-70.3(59.39 \pm 3.93)$ & $\begin{array}{c}52.4-68.7(59.78 \pm \\
3.71)\end{array}$ & 0.05 \\
\hline Semen volume $(\mathrm{mL})$ & $1-5.5(3.65 \pm 1.23)$ & $2.5-5(3.79 \pm 0.71)$ & 0.42 \\
\hline $\begin{array}{c}\text { Sperm count }\left(\mathrm{x}^{6} 0^{6} /\right. \\
\mathrm{mL})\end{array}$ & $14-180(79 \pm 41.47)$ & $38-198(82.1 \pm 42.32)$ & 0.5 \\
\hline $\begin{array}{c}\text { Sperm motility } A+B \\
(\%)\end{array}$ & $18-87(62.73 \pm 16.56)$ & $43-82(65.76 \pm 11.24)$ & 0.05 \\
\hline FSH (mIU/mL) & $1.8-9.1(3.67 \pm 1.62)$ & $1.9-7.1(3.56 \pm 1.19)$ & 0.45 \\
\hline LH (mIU/mL) & $1.6-9.8(5.74 \pm 1.87)$ & $2.9-9.1(5.82 \pm 1.39)$ & 0.55 \\
\hline PRL (ng/dL) & $2.8-17.9(5.77 \pm 3.09)$ & $3.1-9.8(5.71 \pm 1.56)$ & 0.88 \\
\hline Total T (ng/dL) & $\begin{array}{c}328-1013.3(621.85 \pm \\
178.05)\end{array}$ & $\begin{array}{c}418.1-978.4(638.74 \pm \\
144.69)\end{array}$ & 0.19 \\
\hline $\begin{array}{c}\text { Total estrogen } \\
(\mathrm{ng} / \mathrm{dL})\end{array}$ & $1.9-7.2(3.41 \pm 1.34)$ & $2.1-5.4(3.15 \pm 0.82)$ & 0.07 \\
\hline
\end{tabular}

\section{DISCUSSION}

For several decades, protein supplementations and other performanceenhancing substances were used only by bodybuilders and athletes practicing heavy sports. Recently, however, protein supplementations became a common practice among young adult gym-goers wanting to improve their physical appearance (Samal and Samal, 2017).
According to Euromonitor figures, sports nutrition market in Egypt is recording a positive growth and is expected to reach $\mathrm{E} £ 68$ million in 2021. Despite rising prices, demand for sports nutrition products is increasing, with high numbers of young Egyptians becoming more interested in exercising and shaping their muscles (Momaya et al., 2015).

The current study showed that ingestion of whey protein supplementation (15 gram daily for 12 weeks) by regular 
adult gym-goers resulted in a significant increase in both BMI and lean body mass. This is in concordance with many previous studies showing same results (Joy et al., 2013).

BCAAs in whey protein supplementations stimulate muscle protein synthesis and prevent its breakdown (Volek et al., 2013).

The significant increase in the mean percentage of progressively motile sperms may be attributed to the amino acid content of whey proteins. L-arginine is a nitric oxide precursor and acts as a free radical scavenger and anti-oxidant (Tripathi and Misra, 2009) and was shown to increase sperm motility in men with asthenozoospermia (Morgante et al., 2010; Stanislavov and Rohdewald, 2014). $\mathrm{L}$-carnitine, which is synthesised de novo from the two amino acids lysine and methionine, significantly increased percentage of motile sperms in patients with asthenozoospermia (Wang et al., 2010).

Another finding in the results of this study is the non-significant decrease in mean serum oestrogen levels at the end of the 12-week period. The aromatase enzyme within adipose tissue converts testosterone to oestrogens increasing plasma oestrogen levels (Phillips and Tanphaichitr, 2010).

The decrease in serum oestrogen levels may be related to decreased fat mass induced by whey proteins (Flaim et al., 2017). Although non-significant, the decrease in oestrogen level may be of benefit regarding the fertility capacity of males since obesity and hyperestrogenemia have been linked with poor semen parameters such as decreased sperm count and motility and increased abnormal forms and DNA damage (MacDonald et al., 2009).

\section{CONCLUSION}

The results of the current study showed that ingestion of whey proteins (15 gram daily for 12 weeks) by regular adult male gym-goers did not have any negative impact on their fertility parameters. Moreover, this practice may even improve their fertility capacity through improving sperm motility, decreasing fat mass and decreasing serum oestrogen levels.

To our knowledge, this is the first study to examine the impact of whey protein supplementation on fertility capacity of young adult males. This study, however, has some limitations: lack of control group, the relatively low dose and short duration of whey protein supplementations. Further larger and randomized controlled studies using different commercial types of supplementations and comparing different doses and durations are recommended to confirm these findings.

\section{REFERENCES}

1. Flaim, C., Kob, M., Di Pierro, A.M., Herrmann, M. and Lucchin, L. (2017): Effects of a whey protein supplementation on oxidative stress, body composition and glucose metabolism among overweight people affected by diabetes mellitus or impaired fasting glucose: A pilot study. The Journal of Nutritional Biochemistry, 50: 95-102.

2. Josse, A.R. and Phillips, S.M. (2012): Impact of milk consumption and resistance training on body composition of female athletes. Medicine and Sport Science, 59: 94-103.

3. Joy, J.M., Lowery, R.P., Wilson, J.M., Purpura, M., De Souza, E.O., Wilson, S.M., Kalman, D.S., Dudeck, J.E. and Jager, R. (2013): The effects of 8 weeks of whey or rice 
protein supplementation on body composition and exercise performance. Nutrition Journal, 12: 86 .

4. MacDonald, A., Herbison, G., Showell, M. and Farquhar, C. (2009): The impact of body mass index on semen parameters and reproductive hormones in human males: a systematic review with meta-analysis. Human Reproduction Update, 16: 293-311.

5. Millward, D.J., Layman, D.K., Tome, D. and Schaafsma, G. (2008): Protein quality assessment: impact of expanding understanding of protein and amino acid needs for optimal health. The American Journal of Clinical Nutrition, 87: 1576s-1581s.

6. Momaya, A., Fawal, M. and Estes, R. (2015): Performance-Enhancing Substances in Sports: A Review of the Literature. Sports Med, 45:517-531.

7. Morgante, G., Scolaro, V., Tosti, C., Di Sabatino, A., Piomboni, P. and De Leo, V. (2010): Treatment with carnitine, acetyl carnitine, L-arginine and ginseng improves sperm motility and sexual health in men with asthenopermia. Minerva urologica e nefrologica. The Italian Journal of Urology and Nephrology, 62: 213-218.

8. Phillips, K.P. and Tanphaichitr, N. (2010): Mechanisms of obesity-induced male infertility. Expert Review of Endocrinology \& Metabolism, 5: 229-251.

9. Salehi, A., Gunnerud, U., Muhammed, S.J. Ostman, E., Holst, J.J., Bjorck, I. and Rorsman, P. (2012): The insulinogenic effect of whey protein is partially mediated by a direct effect of amino acids and GIP on beta-cells. Nutrition \& Metabolism, 9: 48.
10. Samal, J.R.K. and Samal, I.R. (2017): Protein Supplements: Pros and Cons. Journal of Dietary Supplements, 1-7.

11. Stanislavov, R. and Rohdewald, P. (2014): Sperm quality in men is improved by supplementation with a combination of Larginine, L-citrullin, roburins and Pycnogenol(R). Minerva urologica e nefrologica $=$ The Italian Journal of Urology and Nephrology, 66: 217-223.

12. Tripathi, P. and Misra, M.K. (2009): Therapeutic role of L-arginine on free radical scavenging system in ischemic heart diseases. Indian Journal of Biochemistry \& Biophysics, 46: 498-502.

13. Tsutsumi, R. and Tsutsumi, Y.M. (2014): Peptides and proteins in whey and their benefits for human health. Austin J Nutri Food Sci., 1: 1002.

14. Volek, J.S., Volk, B.M., Gomez, A.L., Kunces, L.J., Kupchak, B.R., Freidenreich, D.J., Aristizabal, J.C., Saenz, C., DunnLewis, C., Ballard, K.D., et al. (2013): Whey protein supplementation during resistance training augments lean body mass. Journal of the American College of Nutrition, 32: 122135.

15. Wang, Y.X., Yang, S.W., Qu, C.B., Huo, H.X., Li, W., Li, J.D., Chang, X.L. and Cai, G.Z. (2010): L-carnitine: safe and effective for asthenozoospermia. National Journal of Andrology, 16: 420-422.

16. World Health Organization (2010): WHO laboratory manual for the examination and processing of human semen (WHO Press, Switzerland). 


\section{تأثير تناول الأحماض الأمينية على معايير الخصوبة للذكور البالغين مرتادى الصالات الرياض الرياضية}

على رمضان ربيع. أحمد كامل صديق عبدالحميد. أبوالفتوح خالد أبوالفتوح محمد* قسمى الأمراض الجلدية و التتاسلية بكلية طب الأزهرو كلية طب الزقازيق*

خلفية البحث : يتناول الذكور البالغين مرتادى الصالات الرياضية الأحماض الأمينية على نطاق واسع

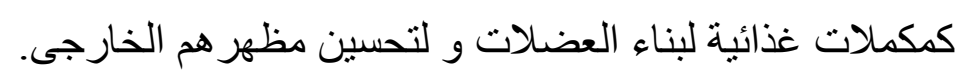

الهلف من البحث: تحديد نأثير تناول الأحماض الأمينية على مستوى الخصوبة.

المشاركون وطرق البحث: تم إجر اء البحث على •ـ من الذكور البالغين مرتادى الصـالات الرياضية

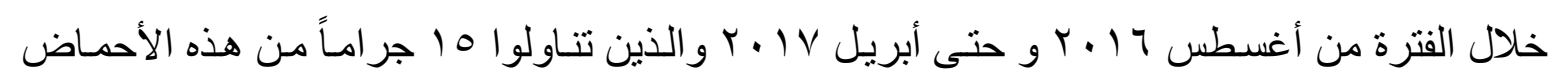

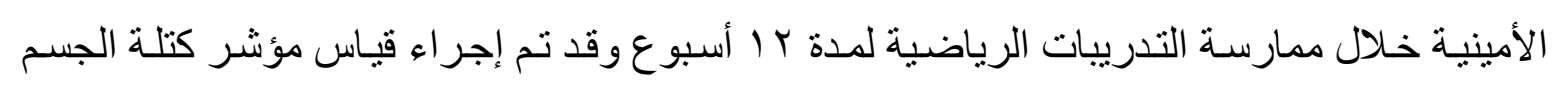

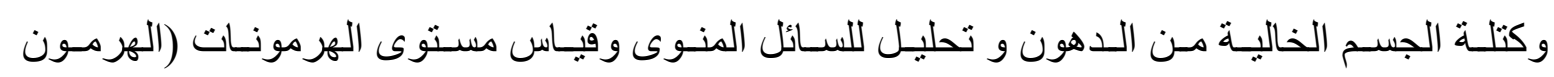

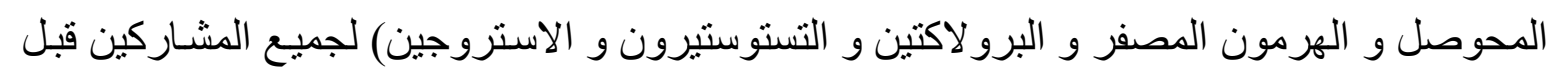
بداية البحث و فى نهايته بعد ب ا اسبوع.

النتائج: فى نهايـة فترة الدراسـة ، كانت هناك زيادات ذات دلالات إحصـائية فى مؤشر كتلـة الجسم

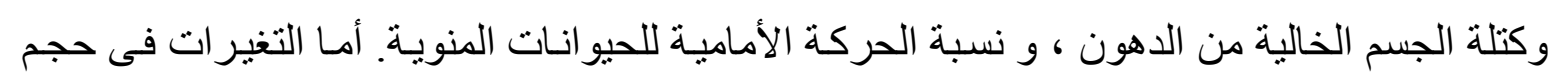
السائل المنوى و عدد الحيو انات المنوية ومستويات الهرمونات فكانت جميعها بدون دلالة إحصائية. الاستنتاج: تناول الأحماض الأمينية لبس لـه تأثير سلبى على مستوى الخصوبة فى الذكور البالغين

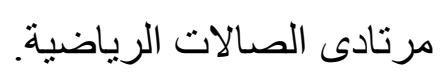

